\title{
The Effects of Argumentation Activities on Seventh Grade Students' Environmental Attitudes and Their Knowledge Level
}

\author{
Mustafa Hamalosmanoğlu*, Serdar Varinlioğlu \\ Department of Science Education, Erciyes University, Faculty of Education, Kayseri, Turkey \\ *Corresponding Author: hamalosmanoglu@erciyes.edu.tr
}

\section{ABSTRACT}

The purpose of the study was to reveal the effects of scientific argumentation-oriented teaching activities on the environmental attitudes and knowledge of seventh-grade Turkish students within the human and environment unit compared to the activities suggested by the ministry of education science and technology curriculum. This study employed a "Quasi-experimental design with pre-test-post-test control group" quantitative research design. A total of 57 seventh-grade students participated in the study, 29 in the test group and 28 in the control group. The research was carried out in a public school in the Melikgazi district of the Kayseri Province in the 2012-2013 academic years, where the study's was conducted over a total of $16 \mathrm{~h}$. Research data were collected through a 24-item environmental knowledge test and a 20 -item environmental attitude scale after granting permission of the researcher who was working on environmental education. Independent samples t-test analyzes were performed for the dependent variable environmental knowledge level. As the scores of the participants were not normally distributed in the environmental attitude scale, the analysis of the scores obtained from this scale was performed by nonparametric Mann-Whitney U-test. As a result of the analysis, it was observed that the participating students' environmental knowledge post-test scores significantly differentiated in favor of the test group $(\mathrm{t}(55)=2.564, \rho=0.013)$. Environmental knowledge post-test results revealed that scientific argumentation-oriented teaching activities were significantly more effective on students' environmental knowledge compared to the control group. However, no significant difference was found between the environmental attitude post-test scores $(U=311.5, \rho=0.129)$. Therefore, it was concluded that teaching activities focused on scientific argumentations had no effect on these students' attitudes toward the environment. Regarding the results of the study, the effect of this method on students' environmental attitudes should be compared at secondary school, high school, and university levels.

KEY WORDS: science education; environmental attitudes; environmental knowledge; argumentation; quantitative research

\section{INTRODUCTION}

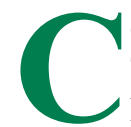
ountries are in constant competition with each other. To be at the forefront of this competition, countries have implemented educational reforms. In response to these reforms, older and more traditional educational approaches started to be replaced by more contemporary and forward-looking approaches. Since the 2005-2006 academic years, innovative teaching methods and techniques have been introduced with the constructivist approach in Turkey (ministry of education [MOE], 2005).

The roots of constructivism are based on Giambattista Vico, who believed that "the learner knows only the cognitive structure he/she builds" (Liang and Gabel, 2005. p. 1144). Scientists such as Piaget, Von Glasersfeld, Bruner, and Vygotsky have contributed to the development of constructivism by starting important movements (Matthews, 1993). Constructivism provides a great advancement in student participation for effective teaching, in understanding current concept schemes of the students, in the formation of dialogue, discussion, argument in a social environment, and in justifying student-teacher ideas compared to rote learning (Matthews, 1993).

Sağır et al. (2008) highlighted that how environmental education has an important place for the future of nations in adapting to change and development occurring in the world. Using the instructional methods proposed by the constructivist approach is seen as important in terms of efficient teaching of environmental education. Environmental education is necessary to raise individuals who are sensitive to environmental problems. The success of the solution of the environmental problems in the world and the way to ensure harmony between humanity and nature go through the individuals who have received environmental education. The training of these individuals is an investment made to the future of our planet. This investment involves discussing human interaction with nature from different perspectives; this is the re-determination of various educational activities and curricula based on the constructivist approach that will create positive environmental attitudes in children. Environmental education and environmental awareness policies have to be 
updated around the world to raise "global citizens" with high environmental knowledge and awareness (Atasoy and Ertürk, 2008; Özbuğutu et al., 2014).

Constructivism also establishes a strong natural relationship between the environment and humans (Şaşan, 2002). The use of a constructivist approach in science education helps people to perceive the world and solve the problems they face (Çelik, 2010). In interpreting what is happening, science education removes science from traditional understanding and allows students to argue in class, helps them to correct mistakes, and supports them thinking like scientists (Sağır, 2008). From this point of view, the use of methods and techniques appropriate to the constructivist approach in science education is important in perceiving and understanding the environment.

\section{LITERATUR REVIEW}

In science classes, the scientific argumentation method plays an important role in the structuring of the information by students through interaction (Gümrah, 2013). Since Aristotle, many thinkers in human history have been interested in scientific argumentation. Many authorities in various fields such as religion, politics, philosophy, and law have relied on the use of scientific argumentation. Similarly, scientists have used arguments to promote theories, models, and explanations about the natural world (Erduran et al., 2006). Arguments are defined as the activities of people (Hakyolu, 2010). One of the most important works in this field is "the uses of argument," which was published by Toulmin in 2003, in which the argument model was included. Although scientific argumentation has long been a field of study, we would argue the most important development took place after this time period. Toulmin (2003) suggested six elements in the argument model. The first three items, claim, data, and warrant, constitute the main part of the argument, whereas the other three elements, backing, rebuttals, and qualifiers are the auxiliary components of the argument. In Figure 1, the six components of Toulmin (2003) are illustrated as a concept map. This argument structure, which contains the basic and auxiliary components, indicates a high-quality strong argument (Osborne et al., 2004).

For this study, the following definitions were used as specified by Toulmin (2003) with the examples from Andriessen's (2007) study:

\section{Data}

They are the facts in the argument that individuals use to support their claims. For example, the statement "in the last century the Earth's temperature has increased as a result of greenhouse gas emissions" contains the data.

\section{Claim}

It is the statement, opinion, or argument put forward by individuals, which forms the basis of all arguments. According to Osborne et al. (2004), the claim includes hypotheses,

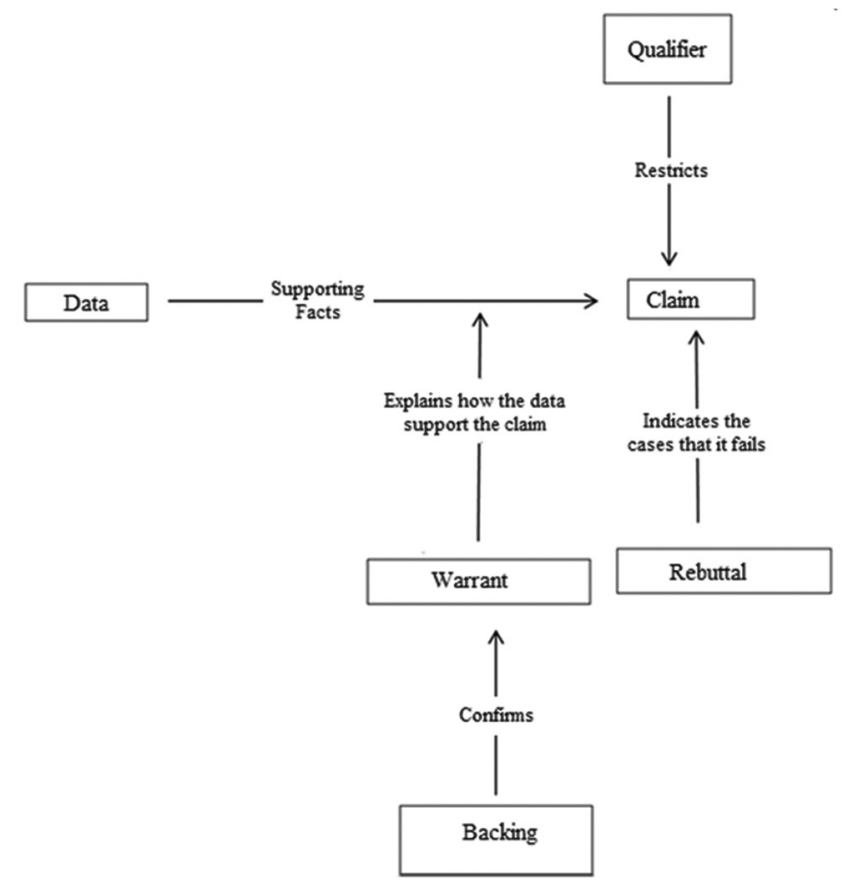

Figure 1: Schematic representation of all components of the Toulmin (2003) argument model. According to Toulmin, the main elements are necessary for an argument to occur, whereas the auxiliary elements increase the validity of the argument (Kaya and Kılıç, 2008, 2010). The data, qualifier, backing, rebuttal, or qualifiers are the components of the evidence (Osborne et al., 2004).

theories, and predictions. Among the argument components, the claim is the most commonly used one because even in the formation of the simplest arguments, the individual can easily make claims. For example, the statement "Kyoto protocol is necessary for the reduction of global warming" contains the claim.

\section{Warrant}

It is the recommended reasons, rules, and principles for justifying the links between the data and claims. For example, the statement "scientists acknowledge that there is no other explanation for this increase in temperature (rather than the Kyoto protocol)" includes the warrant.

These elements form the basis of an argument structure; in addition, Toulmin defined the other components found in more complex arguments as follows:

\section{Qualifier}

It indicates the cases where the claim can be taken as correct; the qualifiers show the limitations on the claim. For example, the statement "however, in some cases, it was found that the Earth's temperature fluctuating according to geological time without no clear reason" includes the qualifier.

\section{Rebuttal}

It indicates the cases where the claim will not occur. Rebuttals are unconventional and exceptional cases that can destroy the effect of backing arguments (Erduran et al., 2004). 
Detailed rebuttals are rarely used by students because they require evidential knowledge that students do not have (Simon et al., 2012). The individual should identify and present his/her specific rebuttals while presenting his/her claim to construct a good argument, which will make it easier for the other party to accept the idea. In this way, individuals achieve better debate skill. For example, the statement "the Kyoto protocol is not required if all countries voluntarily reduce greenhouse gas emissions" includes the rebuttal.

\section{Backing}

They are basic assumptions that are often used to justify the qualifiers. For example, the statement "scientists have described atmospheric mechanisms occurring through greenhouse gases that cause heating on the earth's surface" includes the backing.

There are techniques that facilitate the implementation of Toulmin's argument model in science classes. These techniques are the templates that the teacher can use as instructional materials for providing the students the opportunity to discuss their thoughts (Yeşiloğlu, 2007). Osborne et al. (2004) employed these techniques in their study, which established and facilitated the scientific argumentation in the classroom. The techniques used in science classes as materials that facilitate and support scientific argumentation are: Table of statements, concept map consisting of student claims, discussing a scientific experience taken from the students, competing theoriescartoon, competing theories-story, theories competing with ideas and arguments, constructing an argument, predictionobservation-explanation (POE), and designing an experiment. Through the method of scientific argumentation, students actively formulate and discuss arguments as an individual or in a group. Instead of taking the information as it is, they construct it in their minds and create an attitude toward the environment.

Abroad, research on scientific argumentation has increased since the mid-90s. Science educators assume that scientific argumentation is not only an important aspect of science education but also increases the learning of science content (Aufschnaiter, 2010). In recent years, the importance of the use of scientific argumentations in the classroom has also been noticed in Turkey, and the studies examining its effect on different dependent variables have been conducted (Aldağ, 2006; Altun, 2010; Deveci, 2009; Kaya and Kılıç, 2008; Yeşiloğlu, 2007; Sağır, 2008). In this study, students' environmental attitudes and knowledge levels were chosen as dependent variables. From this point of view, the study will contribute to an area of neglect in the research literature.

In the literature, there are many studies that use academic achievement or knowledge levels in science courses where scientific argumentation is applied as dependent variables (Küçük and Aycan, 2014). It has been observed that academic achievement and knowledge level have been increased in many studies that examined the effect of scientific argumentation on a certain subject and unit success in various class levels in science class (Altun, 2010; Aufschnaiter et al., 2008; Deniz, 2014; Deveci, 2009; Keys et al., 1999; Newton et al., 1999; Niaz et al., 2002; Okumuş, 2012; Özkara, 2011; Sağır, 2008). In the light of these studies, the scientific argumentation method was preferred for this study as it was thought that the knowledge level of the students would be increased within the "human and environment" unit.

There are many studies examining the effect of scientific argumentation on the attitude toward science. A number of studies conducted at various grade levels showed a significant change in the attitude (Balc1, 2015; Doğru, 2016; Erdoğan, 2010; Küçük, 2012; Çakır, 2011), whereas in some studies no change has occurred in attitude toward science (Altun, 2010; Özkara, 2011; Sağır, 2008). However, there are very few studies investigating the effects of scientific argumentation on environmental attitude and environmental knowledge (Burek, 2012; Deniz 2014; Fettahlıŏlu, 2012). In environmental education, there is no study investigating the effect of scientific argumentation on environmental attitudes and knowledge of seventh-grade students. In addition, one of the gains of the science course is rising environmentally literate individuals (Fettahlıoğlu, 2016). Therefore, students' attitudes toward the environment and environmental knowledge should be improved. Considering the importance of gaining environmental consciousness especially for young individuals, it is important to investigate the effect of this method on the environmental attitudes and environmental knowledge of seventh-grade students within the "Human and Environment" unit.

\section{Problem Status}

What is the effect of activities developed according to the scientific argumentation method on seventh-grade students' environmental attitudes and environmental knowledge within the "human and environment" unit in the Melikgazi district of the Kayseri Province, compared to the activities suggested by the curriculum?

\section{METHODOLOGY}

\section{Research Model}

In this study, a pre-test-post-test with control group Quasiexperimental design was used. In the semi-experimental design, two non-random groups were formed, one was called a test group and the other the control group. Measurements related to the dependent variable were performed on the participants in both groups. During the implementation phase, the test group was exposed to the experimental process whose effect was tested, whereas it was not given to the control group. After the implementation phase, measurements related to the dependent variable were again performed on both groups. Therefore, this design included the performance of the pre-test and post-test in both groups (Büyüköztürk et al., 2012). 


\section{Population and Sample}

The targeted population for this research study was all seventhgrade students in the Melikgazi district ( $1^{\text {st }}$ educational region) of the Kayseri Province in Turkey. The study group consisted of 57 students from approximately 1000 students from the target population. Efforts were made to cover at least $5 \%$ of the population in the study due to the problem of obtaining permission for the entire population. As stated, the study was carried out on two groups, test and control groups, whose samples were determined by an appropriate sampling method from non-random sample types. To ensure the equivalence of the groups, the scores achieved from science and technology course during the first semester of the 2012-2013 academic years and the number of students were checked. Twenty of the participants were female (35.1\%) and 37 of them were male (64.9\%) (Table 1).

\section{Data Collection Tools}

Two data collection tools were used in the study, the "environmental attitude scale" and "environmental knowledge test," developed by Bildik (2011).

\section{Environmental attitude scale}

To determine students' environmental attitudes, a 20 -item scale was used. There are ten positive and ten negative statements in the attitude scale. The scale uses a 3-point Likert type, where the answers are "disagree," "indecisive," and "agree." Bildik (2011) stated that the steps of bloom taxonomy's affective domain were taken into consideration while forming the environmental attitude scale. Regarding the reliability of the attitude scale, Bildik (2011) stated that the Cronbach alpha reliability coefficient was found to be $\alpha=0.71$ in SPSS 15.0 , and no item was discarded. The reliability coefficient can take values ranging from 0 to 1 , and the reliability of the scale increases as the value approaches to 1 (Karasar, 2009). According to these results, it can be said that the reliability of the scale is high.

\section{Environmental knowledge test}

Environmental knowledge test was used to determine the environmental knowledge of the participating seventh-grade students. In the development process of the knowledge test, 25 questions were prepared by taking the steps of the bloom taxonomy's cognitive domain into consideration. However, a question was removed from the test by the researcher because its scope validity could not be limited. The gains within the "human and environment" unit and the question numbers belonging to these gains are given in Table 2. It is seen that the questions in the test cover all gains.

Bildik (2011) found the difficulty of the test as $p=0.60$, i.e., medium difficulty, and its discrimination as $\mathrm{D}=0.38$. Büyüköztürk et al. (2008) interpreted item discrimination value between 0.30 and 0.39 as good and these items can be kept in the test without correction (Table 3).

Regarding the environmental knowledge test, Bildik (2011) calculated the Cronbach's alpha reliability coefficient as

\begin{tabular}{lcc}
\hline \multicolumn{3}{l}{ Table 1: Distribution of the sample according to gender } \\
\hline Gender & Number of students & Percentage \\
\hline Female & 20 & 35.1 \\
Male & 37 & 64.9 \\
Total & 57 & 100 \\
\hline
\end{tabular}

\begin{tabular}{ll}
\hline $\begin{array}{l}\text { Table 2: Distribution of knowledge test questions } \\
\text { according to gains }\end{array}$ \\
\hline Item No & Gains \\
\hline 1 & Gain 1 \\
$2,4,5,8$ & Gain 2 \\
12,19 & Gain 4 \\
10 & Gain 5 \\
7 & Gain 6 \\
4 & Gain 7 \\
3 & Gain 8 \\
$6,9,10,11,12,13,15,16,19,20,21,22,23,24$ & Gain 9 \\
6,17 & Gain 10 \\
$14,17,18$ & Gain 11 \\
\hline
\end{tabular}

Table 3: Difficulty and discrimination values of knowledge test

\begin{tabular}{lcc}
\hline Data collection tool & Test difficulty & Test discrimination \\
\hline Knowledge test & 0.60 & 0.38 \\
\hline
\end{tabular}

$\alpha=0.76$, and the KR-20 reliability coefficient of the test as 0.76 . The reliability coefficient can take values ranging from 0 to 1 , and the reliability of the scale increases as the value approaches to 1 (Karasar, 2009). According to these results, it can be said that the reliability of the scale is high.

\section{Data Collection Process}

The following steps were taken in the study conducted to reveal the effects of the scientific argumentation-oriented teaching activities on the environmental attitudes and knowledge of seventh-grade students within the "human and environment" unit compared to the activities suggested by MOE science and technology curriculum:

- The literature about the scientific argumentation method, the attitude toward the environment and the environmental knowledge were reviewed, and both studies from Turkey and abroad were examined.

- The gains of the unit and annual plans prepared by the board of education have been examined. Course plans were prepared for both the control and the test groups. The scientific argumentation activities based on Toulmin's argument model were prepared by the researcher.

- A literature review was performed for the scale to be used in the study, and it was decided to use the environmental attitude scale and environmental knowledge test developed by Bildik (2011), by obtaining his permission.

- The study was carried out in a state secondary school 
in the Melikgazi district of the Kayseri Province, after granting the required permissions. In the execution, the students in the 7/E class formed the test group; and 7/D students, who were equivalent in terms of achievement level, formed the control group.

- A paper introducing scientific argumentation and science education was given to the science and technology teacher who was working in the same school and who administered the educational process of the test and control groups. The study was carried out by the science and technology teacher over a 4-week period under the supervision of the researcher.

- Before the project, the argumentation process was introduced to the teacher in a planned meeting, and the opinions about scientific argumentation activities, and the lesson plans were exchanged with the practitioner teacher.

- The attitude scale and knowledge test were offered to the 57 students in both the control and test group by the researcher, as the pre-test.

- At the end of the study, the attitude scale and knowledge test were again offered to the same groups as the post-test, and the results were analyzed.

The activities used in the classroom had been prepared and organized by the researcher in a way that the scientific argumentation model could be executed as mentioned above. The techniques used in scientific argumentation activities practiced in the classroom, based on Toulmin's argument pattern were:

- Competing theories cartoon

- Create a concept map and constructing an argument

- Prediction-observation-explanation

- Discussing a scientific experience taken from the students

- Theories competing with ideas and evidence

- Competing theories-story

- Statement table.

Students in the test group were divided into groups for scientific argumentations. Students were placed in Groups of 4-5 students. Students were asked to select a group name that was in line with the unit. Worksheets prepared in accordance with the above techniques were distributed to the students, allowing them to make scientific argumentations. In accordance with the curriculum, 16 teaching hours were allocated for the delivery of the "human and environment" unit for both the test and control group. Before starting the unit, students of the test group were exposed to the activities introducing the argument model.

\section{Data Analysis}

Descriptive statistics were checked to determine whether the scores obtained from the participants from the data collection tools were normally distributed or not. For this purpose, the pre-test and post-test scores of the control and test groups (for both data collection tools) were compared in terms of arithmetic mean, mode, median, standard deviation, range, skewness, and kurtosis.
Since the scores of the knowledge test were found to be normally distributed for both control and test group students, post-test scores of both groups were analyzed by independent samples t-test in statistics based on deduction. This test is used when the same variable is measured in two different groups. Independent or unrelated samples mean that the groups have different individuals; that is, individuals are not matched in any way (Büyüköztürk et al., 2012).

Since the scores that control and the test group students achieved from the attitude scale were not normally distributed, Mann-Whitney U-test, which is the nonparametric equivalent of the parametric independent samples t-test, was used to analyze the data obtained from this scale.

\section{FINDINGS AND DISCUSSION}

In this section, first descriptive statistics analysis is covered, followed by the statistical analysis based on the deduction, and then the results of the analysis are presented.

\section{Findings of Descriptive Statistics}

Descriptive statistical analysis was performed to check whether the data obtained from this study showed normal distribution or not. First of all, the mean, mode, and median values of the data obtained from the environmental attitude scale and environmental knowledge test were compared. Then, the skewness and kurtosis were checked. As a result of the analysis, it was found that the pre-test and post-test scores obtained from the environmental knowledge test used in the study showed that the normal distribution and the mean, mode, and median values of each group were close to each other. As shown in Tables 4 and 5, the mean, mode, and median values of the pre-test and post-test scores obtained from the environmental attitude scale were close to each other; however, skewness and kurtosis values of the post environmental attitude test were out of the specified range $(-1$, $+1)$; thus, the date failed the criteria for normal distribution (Büyüköztürk, 2012).

\section{Findings of Statistics Based on Deduction Comparison of environmental knowledge pre-test scores of the test and control groups}

Levene's test was performed to determine whether the variances between the groups were equal or not. As seen in Table 6, the result of Levene's test was not significant for the groups in terms of knowledge pre-test scores $(0.283,>0.05)$. Therefore, the variances of the groups' scores were accepted as equal. Since the variances were considered equal, Sig. 2 value is taken into account. Based on this value (0.432), there was no significant difference between the test and control groups in terms of students' environmental knowledge pre-test scores $(\mathrm{t}(55)=0.56, \rho>0.05)$. Therefore, there was no significant difference between the environmental knowledge scores of test and control groups before the application. In other words, groups were equivalent to each other in terms of environmental knowledge before the application. 


\begin{tabular}{lcccc}
\hline Table 4: Descriptive statistics of the test group & & & \\
Measurements & $\begin{array}{c}\text { Pre-test-environmental } \\
\text { knowledge }\end{array}$ & $\begin{array}{c}\text { Post-test-environmental } \\
\text { knowledge }\end{array}$ & $\begin{array}{c}\text { Pre-test-environmental } \\
\text { attitude }\end{array}$ & $\begin{array}{c}\text { Post-test-environmental } \\
\text { attitude }\end{array}$ \\
\hline Number of students & 29 & 29 & 29 & 29 \\
Lost data & 0 & 0 & 0 & 0 \\
Mean & 10.31 & 16 & 44.96 & 44 \\
Median & 10 & 17 & 42 & 43 \\
Mode & 8 & 18 & 0.547 & 43 \\
Skewness & 0.781 & -0.366 & -0.143 & 1.794 \\
Kurtosis & -0.069 & -1.039 & & 4.331 \\
\hline
\end{tabular}

\begin{tabular}{lcccc}
\hline Table 5: Descriptive statistics of the control group & & \\
\hline Measurements & $\begin{array}{c}\text { Pre-test-environmental } \\
\text { knowledge }\end{array}$ & $\begin{array}{c}\text { Post-test-environmental } \\
\text { knowledge }\end{array}$ & $\begin{array}{c}\text { Pre-test-environmental } \\
\text { attitude }\end{array}$ & $\begin{array}{c}\text { Post-test-environmental } \\
\text { attitude }\end{array}$ \\
\hline Number of students & 28 & 28 & 28 & 28 \\
Lost data & 0 & 0 & 0 & 0 \\
Mean & 9.71 & 13.57 & 46.64 & 42.96 \\
Median & 10 & 14 & 46 & 42 \\
Mode & 6 & 14 & 42 & 42 \\
Skewness & -0.096 & -0.321 & 0.045 & 1.611 \\
Kurtosis & -0.633 & 0.259 & -0.072 & 3.135 \\
\hline
\end{tabular}

\section{Comparison of environmental attitude pre-test scores of the test and control groups}

Levene's test was performed to determine whether the variances between the groups were equal. As seen in Table 7, the result of Levene's test was not significant for the groups in terms of attitude pre-test scores $(0.134>0.05)$. Therefore, the variances of the groups' scores were accepted as equal. Since the variances were considered equal, Sig. 2 value is taken into account. Based on this value (0.188), there was no significant difference between the test and control groups in terms of students' environmental attitude pre-test scores $(\mathrm{t}(55)=-1.33$, $\rho>0.05$ ). In other words, groups were equivalent to each other in terms of environmental attitude scores before the application.

The analysis of the environmental attitude pre-test scores by non-parametric Mann-Whitney U-test is shown in Table 8. Accordingly, there was no significant difference between the test and control groups in terms of environmental attitude pretest scores $(U=322, \rho=0.179)$. In other words, groups were equivalent to each other in terms of environmental attitude scores before the application.

\section{Comparison of environmental knowledge post-test scores of the test and control groups}

As seen in Table 9, the result of Levene's test was not significant for the groups in terms of knowledge post-test scores $(0.288>0.05)$. Therefore, the variances of the groups' scores were accepted as equal. Since the variances were considered equal, Sig. 2 value (assumed) is taken into account. Since this value $(0.013)$ is lower $(0.05,>0.013)$, there was a significant difference between the test and control groups in

\begin{tabular}{|c|c|c|c|c|}
\hline \multirow[t]{2}{*}{ Equal variances } & \multicolumn{2}{|c|}{ Levene's test } & \multicolumn{2}{|r|}{ t-test } \\
\hline & $\mathbf{F}$ & Sig. & df & Sig. (two-tailed) \\
\hline \multicolumn{5}{|l|}{ Knowledge pre-test } \\
\hline Assumed & 1.175 & 0.283 & 55 & 0.432 \\
\hline Not assumed & & & 52.782 & 0.433 \\
\hline
\end{tabular}

terms of students' knowledge posttest scores $(\mathrm{t}(55)=2.56$, $\rho>0.05)$. In this case, a significant difference occurred in favor of the test group whose knowledge post-test average score was higher.

\section{Comparison of environmental attitude post-test scores of} the test and control groups

As seen in Table 10, the result of Levene's test was not significant for the groups in terms of attitude post-test scores $(0.104,>0.05)$. Therefore, the variances of the groups' scores were accepted as equal. Since the variances were considered equal, Sig. 2 value (assumed) is taken into account. Based on this value $(0.215)$, there was no significant difference between the test and control groups in terms of students' environmental attitude $(\mathrm{t}(55)=1.25, \rho>0.05)$.

The analysis of the environmental attitude post-test scores by non-parametric Mann-Whitney U-test is shown in Table 11. Accordingly, there was no significant difference between the test and control groups in terms of environmental attitude post-test scores $(\mathrm{U}=311.5, \rho=0.179)$. 


\begin{tabular}{|c|c|c|c|c|}
\hline \multirow[t]{2}{*}{ Equal variances } & \multicolumn{2}{|c|}{ Levene's test } & \multicolumn{2}{|r|}{ t-test } \\
\hline & $\mathbf{F}$ & Sig. & df & Sig. (2- tailed) \\
\hline \multicolumn{5}{|l|}{ Attitude pre-test } \\
\hline Assumed & 2.313 & 0.134 & 55 & 0.188 \\
\hline Not assumed & & & 49.980 & 0.191 \\
\hline
\end{tabular}

Table 8: Results of the Mann-Whitney U-test comparing environmental attitude pre-test scores of the test and control groups

\begin{tabular}{llccccc}
\hline $\begin{array}{l}\text { Environmental } \\
\text { attitude scale }\end{array}$ & Groups & $\mathbf{n}$ & $\begin{array}{c}\text { Mean } \\
\text { rank }\end{array}$ & $\begin{array}{c}\text { Sum of } \\
\text { ranks }\end{array}$ & U & $\boldsymbol{\rho}$ \\
\hline Pre-test & Test & 29 & 26.1 & 757 & 322 & 0.179 \\
& Control & 28 & 32 & 896 & & \\
\hline
\end{tabular}

\begin{tabular}{|c|c|c|c|c|}
\hline \multirow[t]{2}{*}{ Equal variances } & \multicolumn{2}{|c|}{ Levene's test } & \multicolumn{2}{|r|}{ t-test } \\
\hline & $\mathbf{F}$ & Sig. & df & Sig. (two- tailed) \\
\hline \multicolumn{5}{|l|}{ Knowledge post-test } \\
\hline Assumed & 1.151 & 0.288 & 55 & 0.013 \\
\hline Not assumed & & & 54.300 & 0.013 \\
\hline
\end{tabular}

\begin{tabular}{|c|c|c|c|c|}
\hline \multirow[t]{2}{*}{ Equal variances } & \multicolumn{2}{|c|}{ Levene's test } & \multicolumn{2}{|r|}{ t-test } \\
\hline & $\mathbf{F}$ & Sig. & df & Sig. (two-tailed) \\
\hline \multicolumn{5}{|l|}{ Attitude post-test } \\
\hline Assumed & 0.264 & 0.609 & 55 & 0.215 \\
\hline Not assumed & & & 54.527 & 0.214 \\
\hline
\end{tabular}

\begin{tabular}{|c|c|c|c|c|c|c|}
\hline $\begin{array}{l}\text { Environmental } \\
\text { attitude scale }\end{array}$ & Groups & $n$ & $\begin{array}{c}\text { Mean } \\
\text { rank }\end{array}$ & $\begin{array}{c}\text { Sum of } \\
\text { ranks }\end{array}$ & $\mathbf{U}$ & $\rho$ \\
\hline \multirow[t]{2}{*}{ Post-test } & Test & 29 & 32.26 & 935.5 & 311.5 & 0.129 \\
\hline & Control & 28 & 25.63 & 717.5 & & \\
\hline
\end{tabular}

\section{CONCLUSION}

\section{Environmental Knowledge of the Test and Control Groups}

To determine the effect of the scientific argumentation-oriented teaching activities on the environmental knowledge of the participating seventh-grade students within the "human and environment" unit, t-test analysis was performed on the data obtained from the environmental knowledge test applied to the test and control groups. As a result of the analysis, the environmental knowledge post-test scores of the test and control groups were compared.

Regarding the results of the t-test performed to understand whether the difference between the scores is significant or not, it is seen that they were significant in favor of the test group. Therefore, it can be said that the effect of scientific argumentation-oriented teaching activities on the environmental knowledge of seventh-grade students within the "human and environment" unit was higher than the activities suggested by the MOE science and technology curriculum. This finding obtained as a result of the research is similar to the results of some studies in the literature where scientific argumentation had a positive effect on students' environmental knowledge (Burek, 2012; Deniz, 2014; Fettahlıŏglu, 2012). In addition, research showing the positive effect of scientific argumentation on academic achievement and knowledge within various curriculum units also support the results of this study (Aufschnaiter et al., 2008; Balc1, 2015; Çinici et al., 2014; Deniz, 2014; Deveci, 2009; Doğru, 2016; Erdoğan, 2010; Keys et al., 1999; Newton et al., 1999; Niaz et al., 2002; Okumuş, 2012; Öğreten and Sağır, 2014; Özkara, 2011; Polat, 2014; Tucel, 2016; Uluay, 2012; Sağır, 2008; Hasançebi and Günel, 2013; Zohar and Nemet, 2002).

As predicted by the constructivist approach, achievement and knowledge levels increased with scientific argumentation activities because students were highly active in the process, they formed arguments, they discussed, and they thought critically. Therefore, scientific argumentation should be used more frequently in science classes so that primary and secondary school students in young age groups, who will build the future world, have sufficient knowledge of environmental issues.

\section{Environmental Attitude of the Test and Control Groups}

t-test was performed on the environmental attitude post-test scores of the test and control group students. Since test and control group students' environmental attitude post-test scores failed the criteria to be distributed normally, both the t-test, which is a parametric test and Mann-Whitney U-test, which is the nonparametric equivalent of the t-test, were used in the analysis of the research questions. As a result of the analysis of the t-test and its non-parametric equivalent Mann-Whitney U-test, it was found that there was no statistically significant difference between the groups regarding environmental attitude. In addition, it was observed that the arithmetic means of the environmental attitude post-test of the test and control group students were slightly decreased compared to the arithmetic mean of the pre-test. Therefore, it could be said that the activities prepared according to the scientific argumentation method did not have an effect on the environmental attitude of these seventh-grade students within the "human and environment" unit compared to the activities of the MOE science and technology curriculum.

Unlike the studies indicate that scientific argumentation had a positive effect on the attitude toward the environment 
(Burek, 2012; Deniz, 2014; Fettahlıoğlu, 2012), no significant difference was found in the attitudes of students toward the environment in this study. However, it should be noted that a 5-point Likert scale was used in these studies, whereas a 3 -point Likert scale was used in this study. Since the validity and reliability of a 3-point Likert scale is lower than a 5-point Likert-type scale, this might have an impact on the absence of significant difference in environmental attitudes (Preston and Colman, 2000).

This study is in line with some studies conducted at various grade levels, where scientific argumentation did not cause a significant change in the attitude toward the science and the attitudes toward the chemistry (Altun, 2010; Ceylan, 2012; Özkara, 2011; Sağır, 2008; Yeşiloğlu, 2007). In the study of Bildik (2011), it was found that environmental education given to the students increased the knowledge level of the students, but it did not change their attitudes toward the environment. This study concurs that knowledge does not affect attitude.

There are four main characteristics that should be taken into consideration to understand the concept of attitude, as reported by Muğaloğlu (2006):

- Attitude shows resistance to time

- Attitude can be learned

- Attitudes and behaviors are related

- Attitude changes with personal beliefs.

This study was limited in terms of attitude change due to certain restrictions for class, unit, and time, which can be suggested as another reason for scientific argumentation's failure to make a significant difference in the attitude (Blosser, 1984; Osborne et al., 2003; Özkara, 2011; Sağır, 2008; Yeşiloğlu, 2007). It has been shown that long-term practices, which positively affect student attitudes, are needed for the group work to change the attitude of students (Hevedanlı and Akbayın, 2006; Solmaz, 2010). The fact that the study took place in a time period as short as 4 weeks, maybe the reason for failing to change the attitude of students (Kızkapan, 2015; Özkara, 2011).

In studies, in which scientific argumentation had a positive effect on the attitude toward the environment (Deniz, 2014; Fettahlıoglu, 2012), it has been observed that the implementation period was more than 4 weeks. In addition, these studies have been conducted with high school students and teacher candidates. Therefore, to examine the effect of the scientific argumentation on the attitude toward the environment, further studies should be conducted with secondary school, high school students, and teacher candidates for results to be compared.

Since the attitude is related to behavior, and it changes with the personal beliefs of students, it can be affected by environmental conditions. Thus, it can be said the students' environmental attitudes may be affected by environmental conditions, such as gender (Akı1lı and Yurtcan, 2009; Erol, 2005; Gökçe et al., 2007; Koruoğlu, 2013; Nalçacı and Beldağ, 2012; Navruz, 2016; Özcan, 2016; Varl1, 2014), socioeconomic status of the family, working mother status (Erol, 2005), settlement (Köse, 2010; Uzun, 2007), parent education (Değirmenci, 2012; Koruoğlu, 2013; Köse, 2010; Sadık and Çakan, 2010), the attitude of teachers (Muğaloğlu, 2006). By analyzing the data in terms of these variables, the effect of the method on the attitude can be seen more clearly.

Consecutive implementation of scientific argumentation activities in the classroom may be a reason for the lack of change or even the decrease in the environmental attitude. Some studies have reported that students' environmental attitudes were improved when they were intertwined with the nature throughout the school activities and when they had more opportunities to observe their surroundings (Erten, 2004; Farmer et al., 2007; Keleş et al., 2010). Scientific argumentation techniques can be applied by combining them with activities such as trips that will allow students to make more observations on environmental issues. For example, when POE technique and trip activity are applied together, a positive change in students" environmental attitude can be observed.

As the "human and environment" unit is offered in the last part of the academic year, the warming of the weather might have caused desensitization of the students due to heavy course load (Aypay, 2011), which might have caused students' environmental attitude to decrease. To increase the interest and sensitivity of the students in the last part of the school year, various activities (science festival, project competitions, etc.) can be carried out at the school.

\section{RECOMMENDATIONS}

Some suggestions are offered to researchers who want to use the research findings obtained from these activities and the analysis of the data as a source.

- The research was carried out in a limited period of 4 weeks; for attitude changes, long-term research should be conducted.

- The research was carried out with 57 students; to see the effect of scientific argumentation on attitude more clearly, research should be conducted with larger groups of students.

- The research was carried out within the "Human and Environment" unit of the seventh-grade science and technology course. Studies involving the implementation of the activities prepared according to the scientific argumentation method for different units should be conducted.

- In the research, the effects of activities prepared according to scientific argumentation method on the environmental attitudes and environmental knowledge were examined. Studies examining the effects of the activities prepared according to scientific argumentation methods on different dependent variables should be conducted.

- As the attitude is affected by various conditions, different variables that affect the environmental attitude should be 
investigated. Thus, it could be understood more clearly whether the applied method has an effect on attitude or not.

- Departing from the result that scientific argumentation method did not affect environmental attitude, this method should be applied together with other methods, such as trips, and observations that allow students to examine their surrounding closely.

- The effect of this method on students' environmental attitudes should be compared at secondary school, high school, and university levels.

- The activities prepared according to the scientific argumentation method should be applied in other disciplines besides the science classes.

- The "human and environment" unit is instructed in early May, which might have caused students to be bored and desensitized in the classroom. Scientific argumentation should be used with different techniques such as trips observations and examinations, which will enable the students to integrate with nature, to observe their surroundings more closely, and to develop positive attitude toward the environment.

- In-job training should be provided to the teachers to increase the use of the scientific argumentation method in classrooms.

- Teacher candidates should be taught about the applications of scientific argumentation in elective or field courses in the universities, to increase the use of the scientific argumentation method in classrooms.

\section{ACKNOWLEDGMENTS}

This study is based on the author's master thesis named "the effects of argumentation activities on seventh-grade students" environmental attitudes and their knowledge level."

\section{REFERENCES}

Ak1ll1, M., \& Yurtcan, M.T. (2009). An investigation of prospective science teachers' attitudes towards in terms of different factors (sample of Kazım Karabekir education faculty). Journal of Erzincan Faculty of Education, 11(2), 119-131.

Aldağ, H. (2006). Toulmin discussion model. Çukurova University Journal of Social Sciences Institute, 15(1), 13-34.

Altun, E. (2010). Teaching Light Unit to Elementary School Students Through Argumentation. Master's Thesis, Gazi University, Ankara, Turkey.

Andriessen, J. (2007). Arguing to learn. In: Sawyer, K., (Eds.), The Cambridge Handbook of the Learning Sciences. Cambridge: Cambridge University Press. pp. 443-460.

Atasoy, E., \& Ertürk, H. (2008). A field study about environmental knowledge and attitudes of elementary school students. Journal of Erzincan Faculty of Education, 10(1), 105-122.

Aufschnaiter, C.V. (2010). Argumentation about and understanding of science: Research exploring how to interrelate these two different perspectives. In: Çakmakçı, G., \& Taşar, M.F., (Eds.), Contemporary Science Education Research: International Perspectives. Ankara, Turkey: Pegem Academy. pp. 41-42.

Aufschnaiter, C.V., Erduran, S., Osborne, J., \& Simon, S. (2008). Arguing to learn and learning to argue: Case studies of how students' argumentation relates to their scientific knowledge. Journal of Research in Science
Teaching, 45(1), 101-131.

Aypay, A. (2011). Elementary school student burnout scale for grades 6-8: A study of validity and reliability. Educational Sciences: Theory and Practice, 11(2), 511-527.

Balc1, C. (2015). The Effect of Scientific Argumentation Based Learnings in Teaching of "Cell Division and Inheritance" Units to $8^{\text {th }}$ Grade Students. Master's Thesis, Adnan Menderes University, Aydın, Turkey.

Bildik, G. (2011). The Influence of Environment Unit in the $7^{\text {th }}$ Grade on Students' Attitude toward Environment and their Environment Knowledge. Master's Thesis, Gazi University, Ankara, Turkey.

Blosser, E.P. (1984). Attitude research in science education. Information Bulletin, 1, 1-9.

Burek, K. (2012). The Impact of Socioscientific Issues Based Curriculum Involving Environmental Outdoor Education for $4^{\text {th }}$ Grade Students. Unpublished Doctoral Dissertation, University of South Florida, USA.

Büyüköztürk, Ş. (2012). Manual of Data Analysis for Social Sciences. Ankara: Pegem Academy.

Büyüköztürk, Ş., Çakmak, E.K., Akgün, Ö.E., Karadeniz, Ş., \& Demirel, F. (2008). Scientific Research Methods. Ankara: Pegem Academy.

Büyüköztürk, Ş., Çokluk, Ö., \& Köklü, N. (2012). Statistics for Social Sciences. Ankara: Pegem Academy.

Çakır, B.Z.O. (2011). The Influence of Argumentation Based Instruction on $6^{\text {th }}$ Grade Students" Attitudes Toward Science, Conceptual Understandings of Physical and Chemical Change Topic and Argumentativeness. Master's Thesis, Middle East Technical University, Ankara, Turkey.

Çelik, A.Y. (2010). An Analysis of the Influences of the Teaching Approach Based on Scientific Argumentation on High School Students 'Conceptual Understanding, Attitudes, and Willingness for Argumentation and the Quality of Argumentation. Doctoral Dissertation, Gazi University, Ankara, Turkey.

Ceylan, Ç. (2010). Implementing the Science Writing Heuristıc (Swh) Approach in Science Laboratory Activittes. Master's Thesis, Gazi University, Ankara, Turkey.

Çinici, A., Özden, M., Akgün, A., Herdem, K., Karabiber, H.L., \& Deniz, Ş.M. (2014). Investigating the effectiveness of argumentation based activities supported with concept cartoon. Adlyaman University Journal of Institute of Social Sciences, 7(18), 571-596.

Değirmenci, M. (2012). A study of elementary students' attitudes towards environment according to different variables (example of the province of Kayseri). Journal of European Education, 2(2), 47-53.

Deniz, T. (2014). Use of Socioscientific Argumentation Approach in the Environmental Education. Master's Thesis, Gazi University, Ankara, Turkey.

Deveci, A. (2009). Developing $7^{\text {th }}$ Grade Middle School Students' Socioscientific Argumentation, Level of Knowledge and Cognitive Thinking Skills in the Structure of Matter Subject. Master's Thesis, Marmara University, İstanbul, Turkey.

Doğru, S. (2016). The Influence of Argumentation Based Classroom Activities on $5^{\text {th }}$ Grade Students' Academic Success, Logical Thinking Skills, and Willingness to Discuss. Master's Thesis, Mustafa Kemal University, Hatay, Turkey.

Erdoğan, S. (2010). Investigate the Effects of Teaching Earth, Sun and Moon Topics Through Argumentation on the Success, Attitude and Argumentation Skills of $5^{\text {th }}$ Grade Students. Master's Thesis, Uşak University, Uşak, Turkey.

Erduran, S., Ardaç, D., \& Yakmaci-Guzel, B. (2006). Learning to teach argumentation: Case studies of pre-service secondary science teachers. Eurasia Journal of Mathematics, Science and Technology Education, 2(2), 1-14.

Erduran, S., Simon, S., \& Osborne, J. (2004). TAP ping into argumentation: developments in the application of Toulmin's argument pattern for studying science discourse. Science Education, 88, 915-933.

Erol, G.H. (2005). Primary School Teaching Department Sophomore Students' Attitudes Toward Environment and Environmental Problems. Master's Thesis, Pamukkale University, Denizli, Turkey.

Erten, S. (2004). What is environmental education and environmental awareness, how should be environmental education? Journal of Human and Environmental, 65(66), 83-94.

Farmer, J., Knapp, D., \& Benton, G.M. (2007). An elementary school 
environmental education field trip: Long-term effects on ecological and environmental knowledge and attitude development. The Journal of Environmental Education, 38(3), 33-42.

Fettahlığlu, P. (2012). The Usage of Argumentation-based and Problembased Learning Approaches Intended for Developing the Environmental Literacy of Pre-service Science Teachers. Doctoral Dissertation. Gazi University, Ankara, Turkey.

Fettahlıoğlu, P. (2016). The effect of argumentation based learning approach supported by online argumentation on environmental knowledge awareness. Educational Sciences: Theory and Practice, 12(6), 1311-1336.

Gökçe, N., Kaya, E., Aktay, S., \& Özden, M. (2007). Elementary students' attitudes towards environment. Elementary Education Online, 6(3), $452-468$.

Gümrah, A. (2013). The Methods of Scientific Discussion Methods of Secondary Education Students Understanding Chemical Changes and their Views on the Nature of Science, the Scientrfic Process, Communication and Development. Doctoral Dissertation. Marmara University, İstanbul, Turkey.

Hakyolu, H. (2010). The Performance of the Students in Different Learning Levels in Argument Environments Created in Science Courses. Master's Thesis, Marmara University, İstanbul, Turkey.

Hasançebi, F.Y., \& Günel, M. (2013). Effects of argumentation based inquiry approach on disadvantaged students' science achievement. Elementary Education Online, 12(4), 1056-1073.

Hevedanlı, M., \& Akbayın, H. (2006). The effects of cooperative learning on students' achievement, retention and attitudes in biology teaching. Journal of Ziya Gökalp Education Faculty, 6, 21-31.

Karasar, N. (2009). Scientific Research Method. Ankara: Nobel Publishing.

Kaya, O.N., \& Kılıç, Z. (2008). Argumentative discourse for the effective teaching of science. Journal of Ahi Evran University Kirşehir Education Faculty, 9(3), 89-100.

Kaya, O.N., \& Kılıç, Z. (2010). Types of dialogs and their effects on learning in science classrooms. Journal of Kastamonu Education, 18(1), 115-130.

Keleş, Ö., Uzun, N., \& Uzun, F.V. (2010). The change of teacher candidates" environmental consciousness, attitude, thought and behaviors with nature training project and the assessment of its permanence. Journal of Electronic Social Sciences, 9(32), 384-401.

Keys, C.W., Hand, B., Prain, V., \& Collins, S. (1999). Using the science writing heuristic as a tool for learning from laboratory investigations in secondary science. Journal of Research in Science Teaching, 36(10), 1065-1084.

Kizkapan, O. (2015). The Effect of Project Based Learning to $7^{\text {th }}$ Grade Students' Academic Achievement and Attitude Towards Science on the Structure and Properties of Matter Unit. Master's Thesis, Erciyes University, Kayseri, Turkey.

Koruoğlu, N. (2013). Investigation of High School Students' Environmental Attitudes in Terms of Some Demographic Variables. Master's Thesis, Balıkesir University, Balıkesir, Turkey.

Köse, E.O. (2010). Factors affecting the environmental attitudes of high school students. Turkish Science Education, 7(3), 198-211.

Küçük, H. (2012). The Effect of Using Argumentation Supported Classroom Activities Elementary Education On Students' Conceptual Understandings, Inquiry Learning Skill Perception and Attitudes Towards Science and Technology. Master's Thesis, Muğla Sttkı Koçman University, Muğla, Turkey.

Küçük, H., \& Aycan, H.Ş. (2014). Examining open access studies on argumantation between the years 2007-2012. Journal of Muğla Sitkl Koçman University Education Faculty, 1(1), 82-98.

Liang, L.L., \& Gabel, D.L. (2005). Effectiveness of a constructivist approach to science instruction for prospective elementary teachers. International Journal of Science Education, 27(10), 1143-1162.

Matthews, M.R. (1993). Constructivism and science education: Some epistemological problems. Journal of Science Education and Technology, 2(1), 359-370.

Ministry of Education (MOE). (2005). Illkögretim Fen ve Teknoloji Dersi Öğretim Programı, (Primary Science and Technology Course Curriculum). Ankara: Devlet Kitapları Müdürlüğü Basımevi (Directorate of State Books).

Muğaloğlu, E.Z. (2006). A Model Study Explaining the Views of Science Teachers about the Nature of Science. Unpublished Doctoral
Dissertation, Marmara University, İstanbul.

Nalçac1, A., \& Beldağ, A. (2012). Identifying the environmental attitudes of $7^{\text {th }}$ and $8^{\text {th }}$ grade elementary students (Erzurum sample). Journal of Eastern Geography, 17(28), 141-154.

Navruz, C. (2016). Examination of Environmental Attitudes of Middle School Students in Rural Areas (Erzincan-Çayırlu District Sample). Master's Thesis, Erzincan University, Erzincan, Turkey.

Newton, P., Driver, R., \& Osborne, J. (1999). The Place of argumentation in the pedagogy of school science. International Journal of Science Education, 21(5), 553-576.

Niaz, M., Aguilera, D., Maza, A., \& Liendo, G. (2002) Arguments, contradictions, resistances, and conceptual change in students' understanding of atomic structure. Science Education, 86, 505-525.

Öğreten, B., \& Sağır, Ş.U. (2014). Examining the effectiveness of science teaching based on argumentation. Turkish Science Education, 11(1), 75-100.

Okumuş, S. (2012). The Effects of Argumentation Model on Students' Achievement and Understanding Level on the Unit of "States of Matter and Heat". Master's Thesis, Karadeniz Teknik University, Trabzon, Turkey.

Osborne, J., Erduran, S., \& Simon, S. (2004). Enhancing the quality of argumentation in school science. Journal of Research in Science Teaching, 41, 994-1020.

Osborne, J., Simon, S., \& Collins, S. (2003). Attitudes towards science: A review of the literature and its implications. International Journal of Science Education, 25(9), 1049-1079.

Özbuğutu, E., Karahan, S., \& Tan, C. (2014). Environmental education and its alternative methods. Journal of Mustafa Kemal University Social Sciences Institute, 11(25), 393-408.

Özcan, E. (2016). Examination of Primary School Students' Attitudes Towards Environment. Master's Thesis, Pamukkale University, Denizli, Turkey.

Özkara, D. (2011). Teaching Pressure Subject to $8^{\text {th }}$ Class Students with Activities Based on Scientific Argumentation. Master's Thesis, Adiyaman University, Adiyaman, Turkey.

Polat, H. (2014). The Effect of the Argumentation Method $7^{\text {th }}$ Grade Elementary School in the Structure of Atom Upon the Student Success. Master's Thesis, Inonu University, Malatya, Turkey.

Preston, C.C., \& Colman, A.M. (2000). Optimal number of response categories in rating scales: Reliability, validity, discriminating power, and respondent preferences. Acta Psychologica, 104(1), 1-15.

Sadık, F., \& Çakan, H. (2010). Biology students' environmental knowledge and attitudes towards environmental problems. Journal of Ç.Ü. Social Sciences Institute, 19(1), 351-365.

Sağır, Ş.U. (2008). Investigation of Effectiveness of Argumentation Theory Based Teaching in Science Courses. Doctoral Dissertation, Gazi University, Ankara.

Sağır, Ş.U., Aslan, O., \& Cansaran, A. (2008). The examination of elementary school students' environmental knowledge and environmental attitudes with respect to the different variables. Elementary Education Online, $7(2), 496-511$

Şaşan, H.H. (2002). Constructivist learning. Yaşadıkça Eğitim (Education), $74,49-52$.

Simon, S., Johnson, S., Cavellt, S., \& Parsons, T. (2012). Promoting argumentation in primary science contexts: an analysis of students' interactions in formal and informal learning environments. Journal of Computer Assisted Learning, 28(5), 440-453.

Solmaz, G. (2010). The Effect of Teaching on Conceptual Understanding through Cooperative Learning on Students' Understanding of Environmental Concepts and their Environmental Awareness: An Example of $7^{\text {th }}$ Class 'Human and Environment' Unit. Master's Thesis, Dokuz Eylül University, İzmir.

Toulmin, S. (2003). The uses of Argument. New York: Cambridge University Press.

Tucel, S.T. (2016). Exploring the Effects of Science Writing Heuristic (SWH) Approach on $8^{\text {th }}$ Grade Students' Achievement, Metacognition, and Epistemological Beliefs. Master's Thesis, Middle East Technical University, Ankara.

Uluay, G. (2012). Investigation of the Effect of Scientific Argumentation Based Teaching on Student's Success in Teaching Primary School 
$7^{\text {th }}$ Grade Sclence and Technology Course Force and Motion Unit Teaching. Master's Thesis, Kastamonu University, Kastamonu.

Uzun, N. (2007). A Study on Environmental Knowledge and Attitudes of Secondary School Students. Doctoral Dissertation, Hacettepe University, Ankara.

Varl1, D. (2014). Examination of $8^{\text {th }}$ Grade Primary School Students' Attitudes Towards Environment. Master's Thesis, Gaziosmanpaşa

\section{University, Tokat.}

Yeşiloğlu, S.N. (2007). Teaching Gases Topıc to High School Students Through Argumentation. Master's Thesis, Gazi University, Ankara, Turkey.

Zohar, A., \& Nemet, F. (2002). Fostering students' knowledge and argumentation skills through dilemmas in human genetics. Journal of Research in Science Teaching, 39(1), 35-62. 